\title{
Intersections
}

Canadian Journal of Music

Revue canadienne de musique

\section{Maria Noriega Rachwal. 2015. From Kitchen to Carnegie Hall: Ethel Stark and the Montreal Women's Symphony Orchestra. Toronto: Second Story Press. 193 pp. ISBN 978-1-927583-87-6}

\section{Benita Wolters-Fredlund}

Volume 36, numéro 2, 2016

URI : https://id.erudit.org/iderudit/1051603ar

DOI : https://doi.org/10.7202/1051603ar

Aller au sommaire du numéro

Éditeur(s)

Canadian University Music Society / Société de musique des universités canadiennes

ISSN

1911-0146 (imprimé)

1918-512X (numérique)

Découvrir la revue

Citer ce compte rendu

Wolters-Fredlund, B. (2016). Compte rendu de [Maria Noriega Rachwal. 2015.

From Kitchen to Carnegie Hall: Ethel Stark and the Montreal Women's

Symphony Orchestra. Toronto: Second Story Press. 193 pp. ISBN

978-1-927583-87-6]. Intersections, 36(2), 111-115.

https://doi.org/10.7202/1051603ar

Copyright @ Canadian University Music Society / Société de musique des universités canadiennes, 2018
Ce document est protégé par la loi sur le droit d'auteur. L'utilisation des services d'Érudit (y compris la reproduction) est assujettie à sa politique d'utilisation que vous pouvez consulter en ligne.

https://apropos.erudit.org/fr/usagers/politique-dutilisation/ 


\section{BOOK REVIEWS / RECENSIONS}

Maria Noriega Rachwal. 2015. From Kitchen to Carnegie Hall: Ethel Stark and the Montreal Women's Symphony Orchestra. Toronto: Second Story Press. 193 pp. ISBN 978-1-927583-87-6.

From Kitchen to Carnegie Hall is the kind of book that could aptly be described with the cliché' d phrase "based on the incredible true story." It is about how Canadian Ethel Stark defied the barriers placed against women in the world of symphonic music in the early twentieth century to become a professional violinist and orchestral conductor, and how she created an all-women's symphony in Montreal in the 1940s just to prove to the world that it was possible. As author Maria Noriega Rachwal makes clear, creating a new orchestra from the ground up populated entirely by women during this period is impressive enough; doing it with such a degree of musical excellence as to attract invitations to perform from all over the world, including at New York's Carnegie Hall, is nothing short of astounding. While the writing suffers from issues of style and consistency, at the heart of this book is a story that is indeed "incredible." It should be widely known, discussed and celebrated.

A key contribution this book makes is simply to remind us that while today women can be seen in virtually all professional orchestras, it was not long ago that women's participation in instrumental music was sharply curtailed. Rachwal strategically uses a Prologue chapter to describe the reigning social attitudes about female musicians in the early twentieth century, providing a helpful frame with which to understand the significance of the history that follows. As she explains, women from middle- and upper-class families were encouraged to study music to solidify their class standing and boost their perceived marriageability, but such activity was typically limited to singing or to playing the piano; most other instruments were not considered appropriate for women (1-2). Exceptions were occasionally made for instruments that were small and in the treble range (e.g. violin, flute), but almost never for those that were large or low in range and considered masculine and/or inelegant. Instruments that touched a woman's lips and/or caused unattractive facial contortions when played (e.g. reeds and brass) and those that used perceived immodest postures (e.g. cello) were also deemed inappropriate (2-3). Moreover, it was assumed that women were physically too weak to master instruments 
that required breath support, and not intelligent enough to fully understand or master complex and abstract classical repertoire (3-4).

It was into this historical context that Ethel Stark was born in Montreal, in 1910, to Jewish-Austrian émigré parents. She grew up in a politically progressive, middle-class, and musical family, and began to play the violin at age nine. She demonstrated a prodigious talent that quickly outgrew the opportunities available in Montreal; at 13 she was invited to tour Europe as a protégé by Viennese violin teacher Oscar Morini, but her parents felt she was too young tour abroad alone (11). At 17 she auditioned at the Curtis Institute of Music and won a full scholarship to study there. At Curtis, Stark became known as a dedicated and talented violinist with an uncompromisingly strong work ethic. The apex of her performance career at Curtis was being chosen to play Tchaikovsky's Violin Concerto on the school's prized "Molitor" Stradivarius for a special national broadcast on NBC radio with the Curtis Orchestra under Fritz Reiner. In this performance, she became the first woman ever to perform under Reiner's baton (18).

As impressive as these performance achievements on the violin are, the even more surprising aspect of Stark's time at Curtis is that she also took conducting classes. As Rachwal describes, when Stark asked to audition for Fritz Reiner's conducting class in the beginning of her sophomore year, Reiner-whose authoritarian approach to conducting and teaching were infamous-flatly refused, saying that a conducting class was no place for a woman. Perhaps more than any other professional musical role, conducting was understood as a serious intellectual pursuit not appropriate for women; it was also inconceivable in 1929 that a woman could or should successfully take command over male players. When several further attempts to audition for the class were rebuffed, Stark, who herself possessed a fiery strong will and felt she was being treated unjustly, simply showed up to class on the first day, uninvited (15). Reiner confronted her and asked her to leave, but Stark "would not budge" (16). Reiner eventually relented, and in this unconventional way Stark became the first woman to study conducting at Curtis (16).

Stark finished her studies at Curtis in 1933 eager to begin a professional career in music. As she soon discovered, however, opportunities for women to play symphonic music professionally were very scarce, a situation exacerbated by the Great Depression. Even in New York, where she moved in 1935 to further her career, most instrumental ensembles featuring women were novelty acts with a theatrical character. She eventually secured a spot in the Hour of Charm All-Girl Orchestra, conducted by Phil Spitalny, which offered a decent salary and played music at a sophisticated level. As Rachwal points out, however, it is telling that this group was marketed as group of "charm" rather than talent. Its members were gifted musicians, but they also had to be highly-attractive, young, white, and single. They performed in matching white gowns, with glamorous hair and make-up, and were forced to sign contracts promising to keep their weight under 120 pounds, their hair long, and to date only those approved by management (24). 
Stark eventually grew weary of the "silly shenanigans" of the Hour of Charm ensemble and decided to leave after her second season (29). Collaborating with pianist Sonia Stalin, another Hour of Charm alumna, she began a successful freelance career based in New York City, presenting piano/violin recitals across North America, and co-founding (with Stalin) and conducting the New York Women's Chamber Orchestra in 1938. Eventually, in 1940, she caught the eye of Montreal philanthropist and amateur musician Madge Bowen, who approached Stark with the audacious plan of beginning an all-women's instrumental group in her hometown of Montreal. Stark agreed-on the condition that it would be a full symphony orchestra with strings, winds, and percussion-and the two entrepreneurs set to work to make history.

The rest of the book tells the story, in some detail, of how Bowen and Stark, and the women they recruited into the new Montreal Women's Symphony Orchestra (MWSO), overcame a series of daunting obstacles to achieve this dream. As Rachwal describes, some of these hurdles were common to all large music ensembles starting with limited funds: finding and buying scores and stands; booking an affordable rehearsal space; securing a venue for concerts, etc. However, other struggles they faced were related more specifically to the gender norms and roles of the period; the biggest of these was simply the fact that there was no pool of female players to draw from. As a result, in the early years Stark would take anyone who was willing to learn a new instrument; the only qualification was an ability to read music. While a few seasoned players were found, the majority of the MWSO's original members were true beginners learning their instrument from scratch. Most did not even own the instrument they volunteered to play, so considerable time was spent procuring cheap instruments for them. Stark thus needed to spend far more time fostering basic musicianship in her players than was typical for men's ensembles; in the first year, rehearsals occurred four to five times a week (87). Carving out time to rehearse and practice was also a challenge for women, who had had domestic and childcare responsibilities at home and some of whom also had careers outside the home.

One of the interesting side-effects of their willingness to train players and their solidarity with fellow women was that while the MWSO was unified in gender, it was much more diverse in its class, age, ethnic, and religious makeup than was typical in male symphonies of that period. If a woman was willing to commit to the project, she was accepted. As a result, as Rachwal explains, the group developed into an "eclectic group of female suffragettes" (62). The ensemble included students and grandmothers; society women and the working-class; housewives, teachers, and factory-workers; French and English; and Jewish, Protestant and Catholic. And while most of the players were white, a notable exception was Violet Louis Grant, a young Jamaican-Canadian woman who played clarinet in the MWSO and in so doing became the first black Canadian ever to play regularly in an orchestra.

Amazingly, this rag-tag collective of mostly-beginner musicians gave their first performance after only seven months of rehearsal, on July 31, 1940. They played Beethoven, Bach, Mozart, and Saint-Saëns, and new orchestral 
arrangements of "Oh Canada" and "God Save the King," written by none other than Violet Archer, who played percussion in the MWSO (and would go to become a beloved Canadian composer). This was the first of many successes over the next twenty years or so for the MWSO and for Stark as a conductor, the apex of which was becoming the first Canadian orchestra to play at Carnegie Hall, in 1947. Reviews for this debut concert, like many of their reviews over the years, were positive, but could not resist registering surprise or amusement about the women's ability to play serious and vigorous music. One New York critic commented, for example, that the MWSO's players "came from the North, where men are men and women play trombones" (128).

Through story after story of the group's trials and achievements, Rachwal demonstrates that this orchestra was a labour of love for all involved. So committed was Stark to the success of the ensemble that she turned down an opportunity to be concertmistress of the Pittsburgh Symphony under Fitz Reiner in the 1940s. But in the mid-to-late 1950s, the ensemble began to struggle. Part of the problem, ironically, was that in the post-war era roles for women changed so quickly that the MWSO's better players could pursue opportunities to play in mainstream ensembles, which were starting, very slowly, to become mixedgender ensembles, and which offered payment. As original members retired from the group or died (including co-founder Madge Bowen), it was difficult to find replacements of the same quality and commitment who would volunteer their time. Another issue was their perpetual lack of funds; their requests for government funding were denied again and again (grants were given to the mainstream, mostly-male orchestras instead). These issues combined to spell the demise of this historic ensemble in 1965.

The amazing history of Ethel Stark and the MWSO certainly deserves to be more widely touted than it has been to this point; as someone with an interest in Canadian music history I am stunned that I have not heard this story before. As I have already emphasized in my overview of the book, this important history demonstrates clearly and compellingly how attitudes and behaviors towards women in the symphonic world have changed in the last 100 years.

That said, given the story's importance as well as its potential use in an academic setting, it bears noting that the writing style throughout is inconsistent and, to my mind, unsuitable and unhelpful for the subject at hand. The book includes extended portions, like the prologue, that manage a clear general-audience prose with occasional footnotes or clear explanations in the prose itself for what the sources for the material are. However, the book quickly veers (without explanation) into the style of a novel, complete with quotations reflecting dialogue between various "characters" in the story, and often even the imagined internal thoughts and motivations of these characters, with no indication from the author about source material. For example, the section of the book that explains how the MWSO received its invitation to Carnegie Hall reads as follows:

When the concert ended, Ethel Stark walked off stage and headed straight for her dressing room. She was tired and didn't want to see anybody. Just 
as she was about to open the door, Koudriavtzeff and his colleague ran up to congratulate her.

"We would like to make you an offer," he said. "We want to take the orchestra with us to Carnegie Hall!"

Ethel let out a boisterous laugh. What a sense of humor this man had! Carnegie Hall, indeed. She murmured that it was a good joke and continued to her dressing room.

But the two gentlemen put out their arms to stop her. They reassured her they were serious.

By now Ethel was getting rather annoyed. "Gentlemen, please. I'm in no mood for jokes tonight. I am very tired."

“This is no joke, Miss Stark," insisted the impresario. (112)

There is nothing wrong with telling a vivid story like this one with some dramatic flair and embellishment. But this fiction-style writing is oddly inconsistent with other portions of the book that are written in a non-fiction style, and this kind of writing does not explain adequately where the author is getting her facts, mitigating its credibility as an historical account. Is this material drawn from Stark's unpublished memoir? If so, to what extent? Is the author using her imagination to envisage what might have happened? Is this material based on a second-hand account from someone that was interviewed? If so, who? What did they say? This intermittent fiction-style writing leaves the reader unsure of how to understand the factual claims made in the book, because s/he cannot investigate the evidence on which these claims are based.

My reaction to the book is thus a frustratingly ambivalent one: the story told is an important chapter in the history of music in Canada and a fascinating and illustrative case study in how musical activity is shaped by gender norms and assumptions. On the other hand, its inconsistent writing style is distracting and invites questions about its reliability and accuracy as history. If a second printing of the book appears with a consistent style, and with the source material clarified and acknowledged, I believe it has the potential to become an important and thought-provoking addition to the fields of music and gender and Canadian music history.

Benita Wolters-FredLund

\section{BIOGRAPHY}

Dr. Benita Wolters-Fredlund is Associate Professor and Co-Chair of the music department at Calvin College (Michigan), where she teaches music history. She holds graduate degrees in musicology from the University of British Columbia and the University of Toronto, and she has published on music of the Jewish left in North America, music of the Holocaust, and on the early history of the Canadian League of Composers. 